\title{
Melanoma Tumor-Reactive Autologous Tumor Infiltrating Lymphocyte
}

National Cancer Institute

\section{Source}

National Cancer Institute. Melanoma Tumor-Reactive Autologous Tumor Infiltrating

Lymphocyte. NCI Thesaurus. Code C48814.

Tumor infiltrating lymphocytes (TIL) harvested directly from infiltrate of a patient's melanoma and cultured with interleukin-2 to expand the TIL cell population. Tumor infiltrating lymphocytes have specific activity against the melanoma from which they are derived. Introducing these melanoma tumor-reactive autologous tumor infiltrating lymphocytes back into the same patient may enhance a cytotoxic T-cell-mediated immune response against the melanoma cancer cells. 